\title{
Pengaruh Kepemimpinan Transformasional Terhadap Organizational Citizenship Behaviour (Studi Kasus PT Komatsu Undercarriage Indonesia)
}

\author{
Febyola Veneta $^{1 *}$ dan Sholihati Amalia ${ }^{2}$ \\ ${ }^{1}$ Jurusan Administrasi Niaga, Politeknik Negeri Bandung, Indonesia \\ ${ }^{2}$ Jurusan Administrasi Niaga, Politeknik Negeri Bandung, Indonesia
}

\begin{abstract}
:
The purpose of this research is to analyze the influence of transformational leadership on organizational citizenship behavior. This research uses quantitave descriptive method. The sample in this study was 150 employees of Komatsu Undercarriage Indonesia Ltd, using nonprobability sampling - saturation sampling. The collection of information in this study was conducted by providing questionnaires to employees and analyzed by using descriptive analysis, correlation, regression, coefficient of determination, and hypothesis testing. The results of this study indicate that transformational leadership affects organizational citizenship behavior by 31,5\% and the rest is influenced by other factors. Analysis results show that transformational leadershiphas a significant effect on organizational citizenship behavior.
\end{abstract}

Keywords: transformational leadership, organizational citizenship behavior, employees

\section{PENDAHULUAN}

Sektor alat berat di Indonesia terus mengalami pertumbuhan meski sempat terpengaruh pelambatan ekonomi nasional. Dilansir dari Kementrian Perindustrian Republik Indonesia produksi alat berat tahun 2017 naik sebesar 52,5\% atau sebanyak 1.931 unit dari yang sebelumnya 3.678 unitmenjadi 5.609 unit.

Peningkatan produksi ini terjadi sejalan dengan adanya program pemerintah mengenai pemerataan pembangunan di seluruh wilayah. Ketua Himpunan Alat Berat Indonesia (Hinabi) pun meyakini tren kenaikan tersebut akan terus berlanjut hingga tahun 2018 yang diprediksi mencapai 7.000

\footnotetext{
*Email Korespondensi:

Febyola Veneta

Febyola.veneta@gmail.com
}

unit atau naik sebesar 24,7\% (www. kemenperin.go.id).

Indonesia merupakan pasar yang cukup menjanjikan untuk penjualan alat berat khususnya untuk excavator dan bulldozer karena alat berat tersebut dapat digunakan diberbagai sektor industri seperti pertambangan, kehutanan, konstruksi, dan agro. Berbagai macam merek alat berat pun bersaing untuk terus memperluas pangsa pasarnya seperti Komatsu, Caterpilar, Hitachi, Kobelco, Volvo, Sumitomo, dan lain - lain. Namun, hingga saat ini hanya merek Komatsu lah yang mampu mendominasi pasaran alat berat di Indonesia. Hal ini dapat dibuktikan pada gambar market share alat berat di Indonesia periode 2012 hingga 2017. 


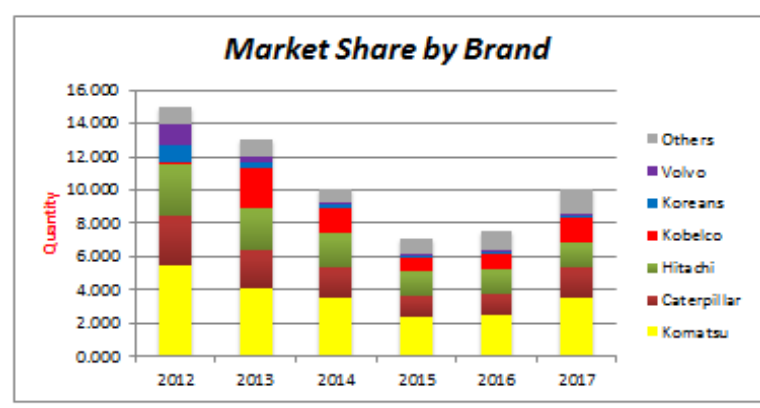

Gambar 1 Market Share by Brand

Berdasarkan gambar 1, dapat diketahui bahwa Komatsu masih tetap menduduki peringkat pertama terlepas dari adanya penurunan penjualan alat berat. Namun, walaupun demikian peningkatan secara signifikan terjadi pada merek others dimana yang sebelumnya berkontribusi sebanyak 1.000 unit menjadi 1.500 unit atau naik sebesar $66 \%$. Persaingan ketat antar perusahaan alat berat pun tidak bisa dihindari. Persaingan yang sangat kompetitif membuat beberapa produsen alat berat untuk melakukan beberapa cara untuk meningkatkan kinerja perusahaannya seperti dengan meningkatkan kinerja karyawannya.

Untuk dapat menunjang kesuksesan suatu organisasi karyawan tidak hanya dituntut untuk memiliki perilaku in-role namun juga perilaku extra-role atau yang biasa disebut dengan Organizational Citizenship Behavior (OCB).

Menurut Cohen dan Vigoda (dalam Jha, 2014) OCB mempunyai efek yang positif untuk organisasi seperti peningkatan produktivitas, efisiensi, dan efektivitas alokasi sumber daya. Karena orientasi mereka terhadap profitabilitas dan eksistensi sebagai entitas sosial, organisasi harus secara umum mempromosikan perilaku OCB di antara karyawan mereka (Miao, 2011; Jha, 2014).

PT Komatsu Undercarriage Indonesia merupakan salah satu Komatsu group yang dikhususkan untuk memproduksi undercarriage untuk excavator dan bulldozer dari berbagai model. Sama seperti perusahaan lainnya PT Komatsu Undercarriage Indonesia pun mempunyai budaya organisasi yang merupakan nilai-nilai dan kepercayaan-kepercayaan yang mencerminkan identitas dari perusahaan tersebut.

Komatsu Way atau yang biasa disebut dengan K-Way merupakan budaya organisasi yang terdapat pada semua Komatsu Grup tak terkecuali PT Komatsu Undercarriage. Budaya organisasi yang terdapat pada PT Komatsu Undercarriage atau K-way terdiri dari 7 pilar, yaitu: komitmen terhadap kualitas dan reliabilitas, orientasi pada pelanggan, mengidentifikasi akar masalah, falsafah tempat kerja (GENBA), penerapan kebijakan (Honshitenkai), bekerjasama dengan mitra bisnis, dan pengembangan SDM.

Terdapat dua faktor utama yang dapat memicu perilaku OCB yakni faktor ekternal dan faktor internal. Faktor internal meliputi kepuasan kerja, komitmen, kepribadian, dan motivasi. Sedangkan faktor ekternal meliputi gaya kepemimpinan, kepercayaan pada pemimpin, dan budaya organisasi (Organ, 2006; Titisari, 2014; Heaviana, 2017). Kepemimpinan memainkan peran penting dalam membina dan meningkatkan perilaku karyawan dalam organisasi. Kepemimpinan transformasional merupakan tipe kepemimpinan dimana seorang pemimpin memotivasi dan mendorong pengikutnya untuk melakukan pekerjaan melebihi standar minimum yang telah ditetapkan (Podsakoff et al, 1990; Humphrey 2012). Karena pemimpin transformasional mampu memotivasi pengikut mereka untuk bekerja di luar tugas pekerjaan mereka, karyawan pun berusaha semaksimal mungkin untuk bekerja melebihi apa yang diharapkan perusahaan atau yang 
biasa disebut OCB. Berdasarkan pengamatan yang telah dilakukan diketahui bahwa para pemimpin yang ada di PT. Komatsu Undercarriage Indonesia mempuyai gaya kepemimpinan transformasional. Hal ini ditandai dengan perilaku pemimpin yang selalu menghargai perbedaan dengan tidak membeda-bedakan latar belakang pendidikan karyawannya, pemimpin yang memberikan kesempatan kepada mahasiswa untuk mengikuti rapat quality control circle (QCC) bersama dengan jajaran manajerial, pemimpin yang menerima ide - ide masukkan dari semua kalangan, pemimpin yang dengan sukarela melakukan pengarahan dan pelatihan kepada karyawan yang membutuhkan, dan perilaku pemimpin yang mampu mendorong karyawannya untuk memunculkan gagasan - gagasan baru (inovasi) melalui kebijakan one man two innovation. Kebijakan one man two innovation merupakan kebijakan dimana pemimpin mengharuskan karyawannya untuk melakukan inovasi setiap enam bulan sekali. Hal ini sesuai dengan pendapat Bass (1999) yang menyatakan bahwa kepemimpinan transformasional merupakan tipe kepemimpinan dimana pemimpin menggunakan pengaruh ideal mereka untuk bertindak sebagai role model, menginspirasi pengikutnya dengan memberikan visi \& misi yang menarik, mendorong karyawan untuk berfikir inovatif, dan menunjukkan perhatian serta kepedulian kepada setiap karyawan.Selain itu, dapat diketahui juga bahwa PT. Komatsu Undercarriage Indonesia merupakan salah satu perusahaan yang melakukan transformasi pada organisasinya. Hal ini ditandai dengan adanya revolusi dibidang teknologi berupa Komatsu machine tracking system atau yang biasa disebut dengan KOMTRAX. KOMTRAX merupakan suatu sistem informasi berbasis internet yang dapat digunakan untuk memantau unit produk Komatsu seperti lokasi, waktu operasional, konsumsi bahan bakar, informasi downtime dan cause, serta maintenance schedule. Tidak hanya itu, PT. Komatsu Undercarriage Indonesia pun memperluas pangsa pasarnya dengan melakukan penjualanke berbagai belahan dunia seperti Amerika, Brazil, Saudi Arabia, Russia, Australia, Kamboja, dan lain - lain.

Wawancara secara informal juga dilakukan terhadap Manager section General Affair Human Resource (HRGA). Berdasarkan hasil wawancara tersebut diketahui bahwa sebelumnya pada bulan April 2018 telah dilakukan survey mengenai kepuasan karyawan. Dari hasil survey tersebut diketahui bahwa motivasi yang ada pada karyawan PT. Komatsu Undercarriage Indonesia mengalami penurunan. Terjadinya penurunan motivasi ini disebabkan karena pemimpin tidak dapat melakukan pengarahan atau coaching terhadap setiap karyawannya. Padahal, motivasi sendiri merupakan hal yang paling penting untuk meningkatkan produktivitas karyawan. Hal ini sesuai dengan pendapat Organ (dalam Heaviana, 2017) yang menyatakan bahwa motivasi merupakan salah satu faktor internal yang dapat menumbuhkan perilaku OCB karyawan. Berdasarkan pengamatan penulis selama melaksanakan kegiatan praktik kerja lapangan diketahui bahwa karyawan yang ada di PT. Komatsu Undercarriage Indonesia sudah menerapkan perilaku OCB. Hal ini ditandai dengan perilaku karyawan yang bersedia menggantikan peran atau pekerjaan rekan kerja yang berhalangan hadir, karyawan memiliki hubungan baik antar sesama rekan kerja, karyawan bersedia membantu proses orientasi lingkungan kerja, dan perilaku karyawan yang selalu mengikuti kegiatan-kegiatan wajib organisasi sepeti 
senam pagi, DMS dan rapat QCC. Namun, di sisi lain juga masih terlihat adanya beberapa karyawan yang mengalami keterlambatan dimanaketerlambatan karyawan dapat menghambat produktivitas perusahaan, karena jam kerja yang dipakai untuk bekerja tidak efektif.

Selain masalah keterlambatan karyawan, beberapa karyawan juga terlihat mengambil waktu istirahat secara berlebihandimana hal tersebutmerupakan salah satu faktor yang dapat menghambat pencapaian target perusahaan serta memberikan pengaruh yang buruk terhadap produktivitas dan kinerja suatu organisasi, hal ini bisa dilihat pada gambar 2 .

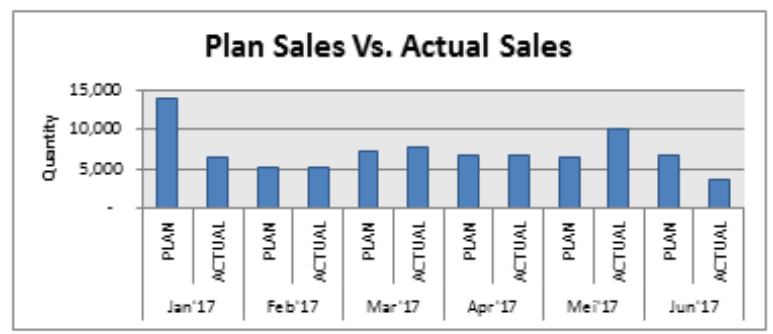

Gambar 2 Data After Market Rolling Forecast Periode Januari - Juni 2017

\section{Rumusan Masalah}

Berdasarkan latar belakang yang telah diuraikan sebelumnya, maka tujuan dari penelitian ini adalah untuk mengetahui:

1. Bagaimana peran kepemimpinan transformasional yang ada di PT Komatsu Undercarriage Indonesia?

2. Bagaimana perilaku kewargaan organisasi PT Komatsu Undercarriage Indonesia?

3. Seberapa besar pengaruh gaya kepemimpinan transformasional terhadap perilaku kewargaan organisasi di PT Komatsu Undercarriage Indonesia?

\section{KAJIAN LITERATUR}

\section{Kepemimpinan Transformasional}

Konsep

kepemimpinan

transformasional pertama kali dikemukakan oleh James MacGregor Burns pada tahun 1978. Dalam penelitiannya, Burns memperkenalkan dua konsep kepemimpinan yaitu "transforming leadership" dan "transactional leadership". Burns (dalam Bass, 1999) mendefinisikan kepemimpinan transformasional sebagai proses di mana para pemimpin dan pengikut saling membantu untuk maju ke tingkat moral dan motivasi yang lebih tinggi. Bass juga mengidentifikasikan bahwa terdapat empat dimensi dari kepemimpinan transformasional, yaitu:

\section{Individualized Consideration}

2. Intellectual Stimulation

3. Inspirational Motivation, dan

4. Idealized Influence

Bass (1999) menyatakan bahwa kepemimpinan transformasional merupakan tipe kepemimpin yang menawarkan pengikut sesuatu yang lebih dari sekadar bekerja untuk keuntungan diri mereka sendiri namun juga mengubah dan memotivasi pengikut melalui pengaruh ideal mereka. Bass juga menekankan bahwa kepemimpinan transformasional memotivasi pengikutnya untuk melampaui harapan dengan membuat mereka menyadari pentingnya suatu tujuan tertentu, membuat mereka mementingkan kepentingan organisasi, dan terus memotivasi mereka untuk menumbuhkan rasa keharusan untuk mencapai target (Bass, 1985; Jha, 2014). Hal ini sejalan dengan pendapat Podsakoff et al (dalam Humphrey, 2012) yang menyatakan bahwa kepemimpinan transformasional merupakan tipe kepemimpinan dimana seorang pemimpin memotivasi dan mendorong pengikutnya 
untuk melakukan pekerjaan melebihi standar minimum yang telah ditetapkan.

\section{Organizational Citizenship Behaviour}

OCB menurut Organ dalam Podsakoff et al (1990) adalah perilaku individual yang bersifat sukarela (discretionary) yang tidak secara langsung dan eksplisit mendapat penghargaan dari sistem imbalan formal, namun dapat meningkatkan efisiensi dan efektifitas fungsi-fungsi organisasi. Sedangkan menurut Robbins dan Judge (2007: 30) OCB merupakan suatu perilaku seseorang yang tidak menjadi bagian dari kewajiban kerja formal seorang karyawan, namun mendukung berfungsinya organisasi tersebut secara efektif.

Organ (dalam Podsakoff et al,1990) mengidentifikasi lima dimensi dalam perilaku OCB, yaitu:

\section{Altruism}

2. Conscientiousness

3. Sportsmanship

4. Courtesy

5. Civic Virtue

Wirawan (2014) menjelaskan bahwa setidaknya terdapat sepuluh faktor yang dapat mempengaruhi perilaku kewargaan organisasional, seperti:

1. Kepribadian

2. Budaya Organisasi

3. Iklim Organisasi

4. Kepuasan Kerja

5. Komitmen Organisasi

6. Kepemimpinan transformasional \& servant leadership

7. Tanggung jawab sosial

8. Umur

9. Keterlibatan kerja

10. Keadilan organisasi
Berikut ini merupakan manfaat dari perilaku kewargaan organisasional menurut Podsakoff et al (2000), yaitu:

1. Meningkatkan produktivitas rekan kerja

2. Meningkatkan produktivitas manajer

3. Menghemat sumber daya yang dimiliki manajemen dan organisasi secara keseluruhan

4. Membantu menghemat energi sumber daya langka untuk memelihara fungsi kelompok

5. Menjadi sarana efektif untuk mengkoordirnasikan kegiatan - kegiatan kelompok kerja

6. Meningkatkan kemampuan organisasi menarik dan mempertahankan karyawan terbaik

7. Meningkatkan stabilitas kinerja organisasi

8. Meningkatkan kemampuan organisasi beradaptasi dengan perubahan lingkungan

\section{Kerangka Pemikiran}

Suatu tujuan organisasi dapat dicapai jika perusahaan menerapkan strategi yang tepat terhadap organisasi dan karyawannya. Salah satu cara yang dapat dilakukan perusahaan untuk meningkatkan kinerjanya adalah dengan memiliki sumber daya manusia yang kompeten dan memiliki kinerja yang tinggi sehingga dapat meningkatkan efektivitas perusahaan. Kinerja karyawan akan berdampak pada pencapaian tujuan organisasi karena organisasi membutuhkan individu yang efektif dan efisien dalam bekerja baik secara personal maupun tim. OCB bisa dipengaruhi banyak hal seperti gaya kepemimpinan, motivasi, komitmen, dan budaya organisasi. Akan tetapi dalam penelitian ini akan dikhususkan bagaimana sebuah gaya kepemimpinan dapat berpengaruh terhadap OCB. 
Sumi Jha (2013) dan Ashkan Khalili (2017) membuktikan bahwa kepemimpinan transformasional mempengaruhi OCB secara positif dan signifikan. Selain itu, penelitian dari Rahmi (2013) membuktikan bahwa kepemimpinan transformasional memiliki dampak yang signifikan terhadap OCB karyawan dengan $59 \%$ varian yang dijelaskan oleh kepemimpinan transformasional. Podsakoff et al dalam Humphrey (2012) menyatakan bahwa kepemimpinan transformasional merupakan tipe kepemimpinan dimana seorang pemimpin memotivasi dan mendorong pengikutnya untuk melakukan pekerjaan melebihi standar minimum yang telah ditetapkan. Menurut Bass dalam Charbonneau (2004) kepemimpinan transformasional merupakan gaya kepemimpinan paling tepat dalam meningkatkan OCB karena pemimpin akan mengubah sikap, nilai, dan keyakinan pengikut mereka untuk menyelaraskannya dengan organisasi serta mengarahkan pengikutnya untuk melakukan pengembangan diri dan melakukan pencapaian yang lebih besar.

OCB merupakan suatu perilaku seseorang yang tidak menjadi bagian dari kewajiban kerja formal seorang karyawan, namun mendukung berfungsinya organisasi tersebut secara efektif (Robbins dan Judge, 2007). Pengukuran gaya kepemimpinan transformasional yang digunakan dalam penelitian ini adalah dimensi menurut Bass (1999) yaitu individualized consideration, intellectual stimulation, inspirational motivation, dan idealized influence. Sedangkan pengukuran OCB menggunakan teori Organ (dalam Podsakoff et al, 1990) yaitu altruism, conscientiousness, sportsmanship, dan civic virtue sebagaimana tergambar pada gambar 3.

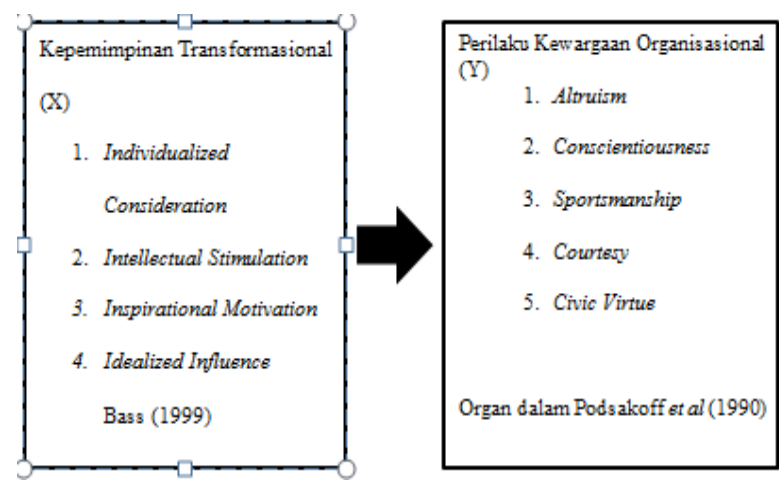

Gambar 3 Paradigma Penelitian

\section{METODE PENELITIAN}

Metode yang digunakan dalam penelitian ini adalah deskriptif kuantitatif. Metode ini bertujuan untuk mengetahui pengaruhkepemimpinan transformasional terhadap OCB.

\section{Populasi dan Sampel}

Populasi dari penelitian ini adalah seluruh karyawan yang bekerja pada bagian office PT. Komatsu Undercarriage Indonesia yang tercatat hingga April 2018 berjumlah sebanyak 150 karyawan yang terdiri dari Departement Administration, Departemen Assurance, Department Plant Control, dan Department Production Engineering \& Maintenance, dan Departement Parts Marketing. Untuk lebih jelasnya dapat dilihat pada tabel 1 .

Tabel 1 Jumlah Karyawan Per Departemen

\begin{tabular}{|c|c|}
\hline Nama Departemen & Jumlah \\
\hline Departemen Administration & 60 Orang \\
\hline Departemen Assurance & 13 Orang \\
\hline Departmen Plant Control & 20 Orang \\
\hline Departmen Production Engineerig \& Maintenance & 40 Orang \\
\hline Departemen Parts Marketing & 17 Orang \\
\hline TOTAL & 150 Orang \\
\hline
\end{tabular}

Metode penarikan sampel yang digunakan adalah non probability samplingsaturation sampling dengan kesalahan sebesar $5 \%$. 


\section{HASIL DAN PEMBAHASAN}

\section{Analisis Deskriptif}

Berdasarkan tabel 2, diketahui bahwa nilai mean dari variabel kepemimpinan transformasional adalah sebesar 4,16 dan termasuk dalam katagori tinggi. Artinya, pemimpin yang ada di PT. Komatsu Undercarriage Indonesia sudah mencerminkan perilaku memberikan pengaruh ideal, perhatian kepada setiap individu, memberikan rangsangan intelektual, dan memberikan motivasi inspirasi. Hal ini sesuai dengan pendapat Luthans dalam Rahmi (2013) yang menyatakan bahwa pemimpin transformasional adalah pemimpin yang berkarisma, menginspirasi, memberikan stimulasi intelektual, dan memperhatikan individu. Oleh karena itu dapat disimpulkan bahwa pemimpin (atasan) yang ada di PT. Komatsu Undercarriage Indonesia sudah menerapkan kepemimpinan transformasional dimana para atasan memiliki sikap individualized consideration, intellectual stimulation, inspirational motivation, dan idealized influence yang baik.

Menurut Castro et al dalam Jha (2013) bahwa dewasa ini kita membutuhkan pemimpin transformasional, yaitu pemimpin yang dapat memotivasi, menginspirasi, memberdayakan, mengartikulasikan visi, dan meningkatkan tujuan pencapaian. Hal ini kemudian diperkuat dengan beberapa penelitian lain yang mengungkapkan pentingnya kepemimpinan transformasional baik di bidang psikologi, leadership, maupun studi organisasi (Podsakpff et al, 1990; Suliman \& Obaidri, 2013). Oleh karena itu, kepemimpinan transformasional diharapkan dapat menjadi salah satu kunci untuk meningkatkan kinerja perusahaan sehingga penting bagi PT Komatsu Undercarriage Indonesia untuk meningkatkan kepemimpinan transformasional pada setiap level jabatan.

Tabel 2 Deskriptif Kepemimpinan Transformasional

\begin{tabular}{|l|r|r|r|r|r|}
\hline & $\mathrm{N}$ & $\begin{array}{c}\text { Minimu } \\
\mathrm{m}\end{array}$ & Maximum & Mean & $\begin{array}{c}\text { Std. } \\
\text { Deviation }\end{array}$ \\
\hline $\begin{array}{l}\text { Dimensi Individualized } \\
\text { Consideration }\end{array}$ & 150 & 1 & 5 & 4.15 & .740 \\
\hline $\begin{array}{l}\text { Dimensi Intellectual } \\
\text { Stimulation }\end{array}$ & 150 & 2 & 5 & 4.20 & .712 \\
\hline $\begin{array}{l}\text { Dimensi Inspirational } \\
\text { Motivation }\end{array}$ & 150 & 2 & 5 & 4.08 & .793 \\
\hline $\begin{array}{l}\text { Dimensi Idealized Influence } \\
\text { Kepemimpinan } \\
\text { Transformasional }\end{array}$ & 150 & 1 & 5 & 4.23 & .727 \\
\hline Valid N (listwise) & 150 & 1 & 5 & 4.16 & .743 \\
\hline
\end{tabular}

Tabel 3 Deskriptif OCB

\begin{tabular}{|l|r|r|r|r|r|}
\hline & $\mathrm{N}$ & Minimum & Maximum & Mean & Std. Deviation \\
\hline Dimensi Altruism & 150 & 1 & 5 & 4.19 & .748 \\
\hline $\begin{array}{l}\text { Dimensi } \\
\text { Conscientiousness }\end{array}$ & 150 & 2 & 5 & 4.15 & .750 \\
\hline $\begin{array}{l}\text { Dimensi } \\
\text { Sportsmanship }\end{array}$ & 150 & 1 & 5 & 4.21 & .760 \\
\hline $\begin{array}{l}\text { Dimensi Courtesy } \\
\text { Dimensi Civic Virtue }\end{array}$ & 150 & 1 & 5 & 4.34 & .668 \\
\hline $\begin{array}{l}\text { Organizational } \\
\text { Cirizenship Behavior }\end{array}$ & 150 & 1 & 5 & 4.19 & .753 \\
\hline Valid N(listwise) & 150 & 1 & 5 & 4.21 & .758 \\
\hline
\end{tabular}

Berdasarkan tabel 3 diketahui bahwa nilai mean dari variabel $\mathrm{OCB}$ adalah sebesar 4,21 dan termasuk dalam katagori sangat tinggi. Rata - rata seluruh dimensi pun berada dalam katagori baik. Hal ini menyatakan bahwa karyawan PT. Komatsu Undercarriage Indonesia sudah mencerminkan perilaku kewargaan organisasi yang ditunjukkan dengan bersedia membantu rekan kerja yang beban kerjanya berlebih, selalu berusaha untuk menyelesaikan tugas/ pekerjaan sebelum waktunya, tidak mengambil waktu istirahat secara berlebihan, tidak pernah mengeluh tentang tugas dan kebijakan perusahaan, selalu menghindari terjadinya perselisihan antar rekan kerja, dan selalu turut berpartisipasi dalam berbagai kegiatan yang diselenggarakan oleh organisasi. Hal ini sesuai dengan dimensi OCB yang dikemukakan oleh Organ (dalam Podsakoff et al, 1990) yang berhasil mengidentifikasi OCB ke dalam lima dimensi yaitu altruism, 
conscientiousness, sportsmanship, courtesy, dan civic virtue.

OCB merupakan suatu perilaku individual yang secara sukarela melakukan pekerjaan melebihi kewajiban kerjanya yang dapat meningkatkan efisiensi dan efektifitas suatu organisasi. Karena perilaku sukarela, maka OCB dilakukan karyawan tanpa mengharapkan imbalan karena memang tidak ada dalam sistem imbalan organisasi. Perilaku OCB yang dilakukan oleh satu karyawan akan menular pada karyawan lainnya sehingga akan menjalar keseluruh departemen bahkan bisa lebih luas lagi.

Hal ini bertolak belakang dengan hasil pengamatan penulis selama observasi yang diketahui bahwa masih ada beberapa karyawan yang mengambil waktu istirahat berlebih. Adanya perbedaan antara hasil pengamatan dengan hasil kuesioner ini disebabkan karena karyawan tidak mengisi kuesioner secara jujur. Ketidakjujuran ini disebabkan karena adanya tekanan untuk menciptakan citra diri yang positif. Hal ini sesuai dengan pendapat Grover \& Hui (2005) yang menyatakan bahwa tekanan kinerja menciptakan suatu ekspektasi untuk berada pada tingkatan tertentu, dan ketika tingkatakan ini tidak dapat dipenuhi maka akan menghasilkan konflik antara apa yang bisa dilakukan dan apa yang orang lain harap kita bisa lakukan. Sehingga karyawan akan memilih berbohong untuk meyelesaikan konflik ini.

\section{Analisis Korelasi}

Uji analisis korelasi yang dilakukan pada penelitian ini menggunakan metode Pearson dan berikut merupakan hasil dari uji korelasi tersebut.
Tabel 4. Uji Korelasi Sederhana

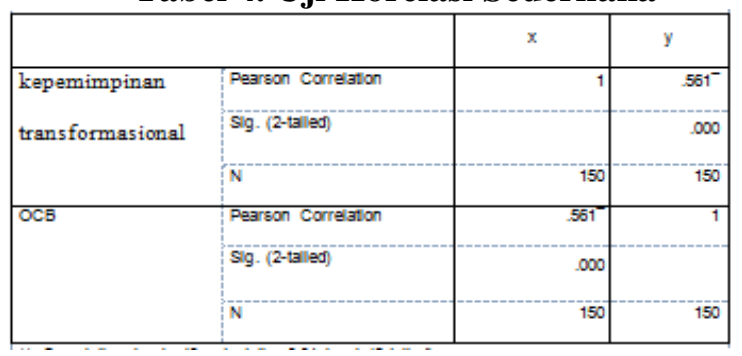

Berdasarkan tabel 4 dapat diketahui bahwa terdapat hubungan antara variabel kepemimpinan transformasional terhadap variabel OCB sebesar 0,561. Jika mengacu pada Sugiyono (2013) maka nilai korelasi tersebut temasuk dalam kategori sedang karena berada di interval 0,40-0,599 yang artinya terdapat hubungan positif yang moderat antara variabel kepemimpinan transformasional terhadap variabel OCB yang berarti jika kepemimpinan transformasional meningkat maka akan diikuti oleh peningkatan OCB.

\section{Analisis Regresi Linear}

Uji regresi yang dilakukan pada penelitian ini adalah uji regresi linear sederhana karena hanya menggunakan satu variabel dependen. Selain itu, analisis regresi juga dapat digunakan untuk memprediksi perubahan nilai kepemimpinan transformasional jika terdapat kenaikan atau penurunan OCB pada karyawan PT Komatsu Undercarriage Indonesia. Berikut ini merupakan tabel yang menunjukan hasil analisis regresi linear sederhana yang dilakukan terhadap 150 responden.

\section{Tabel 5 Hasil Uji Regresi Linear Sederhana}

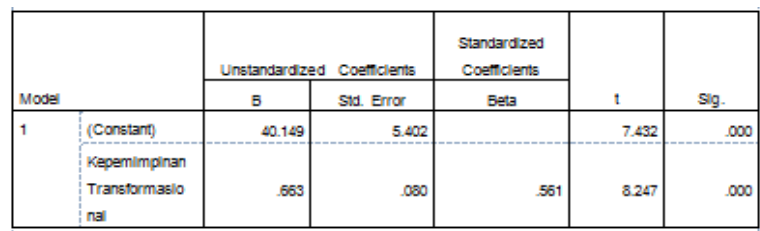


Berdasarkan tabel 5 dapat diketahui bahwa nilai konstanta (a) sebesar 40,149 dan nilai koefisien regresi (b) sebesar 0,663. Berdasarkan data diatas maka diperoleh persamaan regresi sebagai berikut:

$$
\mathrm{Y}=40,149+0,663 \mathrm{X}
$$

Nilai a dan b di atas dapat diinterpretasikan sebagai berikut:

Konstanta (a) sebesar 40,149 dapat diartikan jika kepemimpinan transformasional nilainya sama dengan nol $(X=0)$, maka nilai perilaku OCB nilainya positif 8,535 . Koefisien regresi (b) variabel kepemimpinan transformasional sebesar 0,663 yang artinya jika kepemimpinan transformasional mengalami kenaikan satu satuan maka perilaku OCB karyawan akan mengalami kenaikan sebesar 0,663 satuan. Koefisien bertanda positif artinya terjadi hubungan positif antara kepemimpinan transformasional dan OCB. Hal ini menunjukkan bahwa apabila kepemimpinan transformasional meningkat di mata karyawan, maka OCB karyawan pun akan meningkat.

\section{Koefisien Determinasi}

Koefisien determinasi ini berfungsi untuk mengetahui persentase besarnya pengaruh variabel independent dan variabel dependent. Koefisien determinasi dapat dilihat pada tabel 6 .

Tabel 6 Koefisien Determinasi

\begin{tabular}{|l|r|r|r|r|}
\hline & & & & \multicolumn{1}{|c|}{$\begin{array}{c}\text { Sid. Error of the } \\
\text { Estmate }\end{array}$} \\
\hline 1 & $\mathrm{R}$ & $\mathrm{R}$ Square & Adusted $\mathrm{R}$ Square & \multicolumn{3}{|c|}{8.538} \\
\hline
\end{tabular}

Pada tabel 6 dapat diketahui bahwa nilai koesifien determinasinya adalah sebesar 0,315 yang artinya bahwa kepemimpinan transformasional berkontribusi sebesar 0,315 atau 31,5 \% terhadap perilaku OCB karyawan PT Komatsu Undercarriage Jurnal Riset Bisnis dan Investasi Vol. 4, No. 3, Desember 2018 ISSN 2460-8211
Indonesia, sedangkan sisanya sebesar $68,5 \%$ dipengaruhi oleh faktor - faktor lainnya yang tidak diteliti dalam penelitian ini.

\section{UJI HIPOTESIS}

\section{Uji Signifikansi Simultan (Uji F)}

Uji $F$ dilakukan untuk mengetahui apakah model regresi linier yang digunakan dilihat sudah tepat atau belum. Hasil uji statistik F dilihat pada tabel 7.

\section{Tabel 7 Uji Statistik F}

\begin{tabular}{|c|c|c|c|c|c|c|}
\hline \multicolumn{2}{|c|}{ Mojal } & Sum of Squares & at & Mean Square & $F$ & Siq. \\
\hline \multirow[t]{3}{*}{1} & Regression & 4957.651 & 1 & 4957.651 & 68.005 & $.0000^{\circ}$ \\
\hline & Residual & 10709.343 & 143 & 72.901 & & \\
\hline & Total & 15746.993 & 129 & & & \\
\hline
\end{tabular}

Berdasarkan tabel 7 dapat diketahui bahwa nilai signifikan pada kolom sig adalah 0,000 dimana nilai tersebut lebih kecil dari pada $\alpha=0,05$. Dari tabel diatas juga diketahui bahwa nilai $\mathrm{F}$ hitung $\left(\mathrm{F}_{0}\right)$ adalah sebesar 68,005 dengan menggunakan tingkat signifikansi 0,05 serta df1 : (k-1) 2-1 = 1 dan df $2:(\mathrm{n}-\mathrm{k})=150-2=148$ sehingga diperoleh F tabel (F1) sebesar 3,91. Menurut Aikunto dalam Heaviana (2017) jika $F_{0}$ lebih besar dari pada $\mathrm{F} 1$ dengan tingkat signifikansi 5\% maka $\mathrm{HO}$ ditolak dan $\mathrm{Ha}$ diterima. Oleh karena itu dapat disimpulkan bahwa kepemimpinan transformasional berpengaruh secara signifikan terhadap OCB.

\section{Uji Statistik t}

Uji statistik $t$ pada dasanya menunjukkan seberapa jauh pengaruhsuatu variabel independent atau bebas secara individualdalam menerangkan variabel dependent atau terikat.

\section{Tabel 8 Hasil Uji Statistik t}

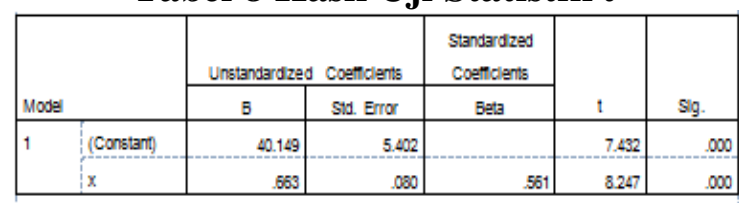


Berdasarkan tabel di atas dapat diketahui bahwa nilai signifikan pada kolom sig adalah 0,000 dimana nilai tersebut lebih kecil dari pada $\alpha=0,05$. Dari tabel diatas juga diketahui bahwa nilai t hitung sebesar 8,247. Dengan rumus $\mathrm{df}=$ jumlah data -1 atau 150 $-1=149$ maka diperoleh nilai $t$ tabel sebesar 1,97601 yang dimana thitung lebih besar dari t tabel $(8,247>1,97601)$. Menurut Priyatno dalam Heaviana (2017) jika t hitung t hitung $>\mathrm{t}$ tabel, maka $\mathrm{H} 0$ ditolak. Oleh karena dapat disimpulkan bahwa kepemimpinan transformasional berpengaruh secara signifikan terhadap OCB.

\section{Pengaruh Kepemimpinan \\ Transformasional Terhadap $O C B$}

Berdasarkan hasil pengolahan data, diketahui bahwa terdapat hubungan antara kepemimpinan transformasional terhadap OCB. Hal ini didapatkan dari hasil analisis korelasi antara variabel kepemimpinan transformasional dan OCB yaitu sebesar 0,561 yang termasuk dalam hubungan positif yang moderat. Kemudian berdasarkan hasil regresi linear sederhana, didapatkan persamaan $\mathrm{Y}=40,149+0,663 \mathrm{X}$ yang dapat diartikan jika kepemimpinan transformasional bernilai $(X=0)$, maka OCB yang tercapai sebesar 40,149 dan setiap adanya peningkatan nilai kepemimpinan transformasional sebesar satu angka, maka OCB akan meningkat sebesar 0,663. Selanjutnya, berdasarkan hasil koefisien determinasi menunjukan bahwa kepemimpinan transformasional berkontribusi sebesar 0,315 atau 31,5\% terhadap perilaku OCB karyawan PT Komatsu Undercarriage Indonesia, sedangkan sisanya sebesar $68,5 \%$ dipengaruhi oleh faktor - faktor lainnya yang tidak diteliti dalam penelitian ini. Berdasarkan uji statistik $F$ dan $T$ juga menunjukkan bahwa kepemimpinan transformasional berpengaruh secara signifikan terhadap OCB.

Penelitian ini membuktikan bahwa kepemimpinan transformasional mempengaruhi OCB secara positif dan signifikan. Hal ini mendukung hasil penelitian dari Sumi Jha (2013) dan Ashkan Khalili (2017) yang membuktikan bahwa kepemimpinan transformasional mempengaruhi OCB secara positif dan signifikan. Selain itu, penelitian dari Rahmi (2013) membuktikan bahwa kepemimpinn transformasional memiliki dampak yang signifikan terhadap OCB karyawan dengan $59 \%$ varian yang dijelaskan oleh kepemimpinan transformasional.

Menurut Bass dalan Charbonneau (2004) kepemimpinan transformasional merupakan gaya kepemimpinan paling tepat dalam meningkatkan OCB karena pemimpin akan mengubah sikap, nilai, dan keyakinan pengikut mereka untuk menyelaraskannya dengan organisasi serta mengarahkan pengikutnya untuk melakukan pengembangan diri dan melakukan pencapaian yang lebih besar. Pengaruh yang ditunjukkan oleh kepemimpinan transformasional terhadap OCB menjadikan peningkatan kepemimpinan transformasional sebagai fokus utama untuk meningkatkan OCB. Oleh karena itu, penting untuk dilakukan peningkatan kepemimpinan transformasional pada setiap level jabatan untuk dapat memberikan pengaruh yang menginspirasi para karyawan untuk melakukan pekerjaan secara sukarela terhadap perusahaan. Pemimpin yang transformasional juga akan meningkatkan perilaku OCB dalam dirinya sehingga dapat menjadi role model untuk pada karyawannya dalam melakukan pekerjaan melebihi harapan perusahan. 
Telah diketahui bahwa terdapat beberapa dimensi yang sudah baik dan sangat baik dalam variabel - variabel di penelitian ini. Oleh karena itu, penelitian ini diharapkan dapat menjadi masukkan dan bahan evaluasi bagi perusahaan. Penelitian ini juga dapat menjadi pertimbangan bagi manajer untuk melakukan suatu tindakan guna mempertahankan dan meningkatkan perilaku OCB pada karyawan. Dari perspektif praktis, hasil penelitian ini menunjukkan bahwa penting bagi para pemimpin untuk memotivasi karyawannya, karena motivasi tersebut akan sangat berpengaruh untuk meningkatkan kinerja karyawan. Sehingga tidak akan ada lagi karyawan yang terlambat maupun karyawan yang menggunakan jam istirahat berlebih.

\section{KESIMPULAN DAN SARAN \\ Kesimpulan}

1. Kepemimpinan transformasional yang ada pada PT. Komatsu Undercarriage Indonesia berada pada kategori tinggi. Hal ini dikarenakan pemimpin selalu menghargai perbedaan dengan tidak membedabedakan latar belakang pendidikan karyawannya, pemimpin menerima ide-ide masukkan dari semua kalangan, pemimpin dengan sukarela melakukan pengarahan dan pelatihan kepada karyawan yang membutuhkan, dan perilaku pemimpin yang mampu mendorong karyawannya untuk memunculkan gagasan-gagasan baru (inovasi) melalui kebijakan one man two innovations. Dimensi idealized influence memiliki nilai mean tertinggi yaitu 4,23 dan masuk kategori sangat tinggi. Sedangkan dimensi inspirational motivation memiliki nilai mean terendah yaitu 4,08 dan termasuk kategori tinggi.

2. Perilaku OCB yang ada pada PT. Komatsu Undercarriage Indonesia berada pada kategori sangat tinggi. Hal ini ditandai dengan perilaku karyawan yang bersedia menggantikan peran atau pekerjaan rekan kerja yang berhalangan hadir, karyawan memiliki hubungan baik antar sesama rekan kerja, karyawan bersedia membantu proses orientasi lingkungan kerja, dan perilaku karyawan yang selalu mengikuti kegiatan-kegiatan wajib organisasi sepeti senam pagi, DMS dan rapat QCC. Dimensi courtesy memiliki nilai mean tertinggi yaitu 4,34dan masuk kategori sangat tinggi. Sedangkan dimensi conscientiousness memiliki nilai mean terendah yaitu 4,15 dan termasuk kategori tinggi.

3. Besarnya pengaruh kepemimpinan transformasional terhadap perilaku OCB di PT. Komatsu Undercarriage Indonesia yaitu sebesar $31,5 \%$. Sisanya sebesar $68,5 \%$ dipengaruhi oleh faktor-faktor lain yang tidak dijelaskan dalam penelitian ini seperti kepuasan kerja, komitmen, kepribadian, motivasi, dan budaya organisasi.

\section{Saran}

1. Untuk mengetahui keabsahan objek penelitian maka diharapkan peneliti selajutnya dapat melakukan penelitian dengan membandingkan variabel $x$ lain seperti motivasi, kinerja karyawan, atau pun gaya kepemimpinan yang berbeda. 
2. Diharapkan agar penelitian ini dapat dilanjutkan oleh peneliti selanjutnya dengan membandingkan objek penelitian yang lebih luas lagi serta dengan karakteristik yang berbeda.

\section{DAFTAR PUSTAKA}

Bass, B. M. (1999). Two decades of research and development in transformational leadership. European journal of work and organizational psychology, 8 (1), 9-32.

Charbonneau, D. (2004). Influence tactics and perceptions of transformational leadership. Leadership

Organization

Development Journal, 25 (7), 565-576.

Grover, S. L., \& Hui, C. (2005). How job pressures and extrinsic rewards affect lying behavior. International Journal of Conflict Management, 16 (3), 287 300.

Heaviana, R. C. (2017). Pengaruh Kepemimpinan Otentik Terhadap Perilaku Kewargaan Organisasional (Studi di Hypermart Bandung). Skripsi. Politeknik Negeri Bandung.

Humphrey, A. (2012). Transformational leadership and organizational citizenship behaviors: The role of organizational identification. The Psychologist-Manager Journal, 15 (4), 247-268.
Jha, S. (2014). Transformational leadership and psychological empowerment: Determinants of organizational citizenship behavior. South Asian Journal of Global Business Research, 3 (1), 18-35.

Khalili, A. (2017). Transformational leadership and organizational citizenship behavior: The moderating role of emotional intelligence. Leadership \& Organization Development Journal, 38 (7), 1004-1015.

Podsakoff, P. M., MacKenzie, S. B., Moorman, R. H., \& Fetter, R. (1990). Transformational leader behaviors and their effects on followers' trust in leader, satisfaction, and organizational citizenship behaviors. The leadership quarterly, 1 (2), 107-142.

Podsakoff, P. M., MacKenzie, S. B., Paine, J. B., \& Bachrach, D. G. (2000). Organizational citizenship behaviors: A critical review of the theoretical and empirical literature and suggestions for future research. Journal of management, 26 (3), 513-563.

Wirawan. (2014). Kepemimpinan: Teori, Psikologi, Perilaku Organisasi, Aplikasi dan Penelitian. Jakarta: PT. Raja Grafindo Persada. 